\title{
Metadherin regulates epithelial-mesenchymal transition in carcinoma
}

This article was published in the following Dove Press journal:

OncoTargets and Therapy

21 April 2016

Number of times this article has been viewed

\author{
Zhao Wang ${ }^{1,2}$ \\ Zheng-yan Tang ${ }^{2}$ \\ Zhuo Yin' \\ Yong-bao Wei ${ }^{1,3}$ \\ Long-fei Liu ${ }^{2}$ \\ Bin Yan' \\ Ke-qin Zhou' \\ Ye-qi Nian' \\ Yun-liang Gao' \\ Jin-rui Yang' \\ 'Department of Urology, The Second \\ Xiangya Hospital, Central South \\ University, Fu Rong District, Changsha, \\ ${ }^{2}$ Department of Urology, Xiangya \\ Hospital, Central South University, \\ Kai Fu District, ${ }^{3}$ Department of \\ Urology, Fujian Provincial Hospital, \\ The Teaching Hospital of Fujian \\ Medical University, Fuzhou, People's \\ Republic of China
}

\begin{abstract}
Metadherin $(M T D H)$ was first identified in primary human fetal astrocytes exposed to HIV-1 in 2002 and then recognized as an important oncogene mediating tumorigenesis, progression, invasiveness, and metastasis of carcinomas. Epithelial-mesenchymal transition (EMT) is a vital process in embryonic development, organ repair, and cancer progression. MTDH and EMT have also been proved to be related to the prognosis of patients with cancers. Recent studies reveal a relationship between MTDH overexpression and EMT in some malignancies. This review highlights the overexpression of MTDH and EMT in cancers and their correlations in clinical studies. Positive correlations have been established between MTDH and mesenchymal biomarkers, and negative correlations between MTDH and epithelial biomarkers have also been established. Furthermore, experiments reveal EMT regulated by MTDH, and some signal pathways have been established. Some anticancer drugs targeting MTDH and EMT are introduced in this review. Some perspectives concerning EMT regulation by MTDH are also presented in this review.
\end{abstract}

Keywords: signal pathway, chemoprevention, oncogene, biomarker, progression, therapeutic target

\section{Introduction}

Metadherin (MTDH) is also known as lysine-rich carcinoembryonic antigen-related cell adhesion molecule (CEACAM)-1-coisolated (LYRIC) protein and astrocyte elevated gene-1 (AEG-1) protein. ${ }^{1,2}$ MTDH was first identified in primary human fetal astrocytes exposed to HIV-1 in 2002, ${ }^{3}$ and then some researchers found that MTDH was overexpressed in many cancer tissues and cell lines. ${ }^{4,5} \mathrm{MTDH}$ has been considered a vital oncogene located in 8q22. ${ }^{6,7}$ Further investigations and studies reveal that MTDH also mediates tumor progression, angiogenesis, invasiveness, metastasis, and chemotherapy resistance..$^{4-9}$ MTDH overexpression may serve as an important biomarker to predict prognosis in clinical retrospective analyses. ${ }^{1,10}$ Signal pathways and drugs or molecular targets of MTDH have also been studied, which have indicated potential therapeutic effects of MTDH in malignancies. ${ }^{1,5,11,12}$

Epithelial-mesenchymal transition (EMT) refers to a morphogenetic process in which cells lose epithelial polarization and gain mesenchymal characteristics, such as motility and invasiveness. ${ }^{13}$ During EMT, epithelial biomarkers (such as E-cadherin and cytokeratin) are downregulated, while mesenchymal biomarkers (such as vimentin) are upregulated, accompanied by changes of transcriptional factors in the process. ${ }^{14,15}$ EMT originates from embryonic development, and then in cancers, it extends to progression and metastasis. ${ }^{13,14}$

The relationship between MTDH expression and EMT has been established in some cancers. ${ }^{2,10,12,15}$ This review highlights the overexpression of MTDH and EMT
Correspondence: jin-rui Yang Department of Urology, The Second Xiangya Hospital, Central South University, I 39 Ren Min Road, Fu Rong District, Changsha 4I00II, People's Republic of China

Tel +86 I36 07443048

Fax +86 73। 8529 5I34

Email xy2yangjinrui@163.com (c) (7) (3) 2016 Wang et al. This work is published and licensed by Dove Medical Press limited. The full terms of this license are available at https://www.dovepress.com/terms.php c. hereby accept the Terms. Non-commercial uses of the work are permitted without any further permission from Dove Medical Press Limited, provided the work is properly attributed. For permission for commercial use of this work, please see paragraphs 4.2 and 5 of our Terms (https://www.dovepress.com/terms.php). 
biomarkers in cancers and their clinical significance (summed up in Table 1). Signal pathways of EMT regulated by MTDH are also involved. Drugs regulating MTDH and EMT are introduced in this review.

\section{MTDH and EMT biomarkers expressed in malignancies}

Overexpressed MTDH has been detected in many types of malignant states, such as gastric carcinoma, hepatocellular carcinoma, colorectal carcinoma, breast cancer, non-small-cell lung cancer, and prostate cancer., 4,7,8,16-20 EMT, elevated mesenchymal markers, and decreased epithelial biomarkers have also been found in malignancies. ${ }^{21,22}$ Combined detection of MTDH and EMT biomarkers in malignancies shows a relationship between these biomarkers in carcinomas.

A study ${ }^{23}$ involving 158 hepatocellular carcinoma specimens and matched normal tissues showed that expression of

Table I Current research on EMT regulation by MTDH (AEG-I) in carcinoma

\begin{tabular}{|c|c|c|c|c|c|}
\hline $\begin{array}{l}\text { First } \\
\text { author }\end{array}$ & $\begin{array}{l}\text { Publication } \\
\text { year }\end{array}$ & Cancer type & Specimens & Main conclusions & References \\
\hline Liu et al & 2014 & $\begin{array}{l}\text { Cervical } \\
\text { cancer }\end{array}$ & $\begin{array}{l}\text { Human tissue } \\
\text { samples, HeLa }\end{array}$ & $\begin{array}{l}\text { Inhibition of MTDH expression decreased migration, invasiveness, } \\
\text { EMT, and chemoresistance in cervical cancer }\end{array}$ & 2 \\
\hline Liu et al & 2013 & LSCC & $\begin{array}{l}\text { Human tissue } \\
\text { samples }\end{array}$ & $\begin{array}{l}\text { A negative correlation between MTDH and E-cadherin has been } \\
\text { established in LSCC }\end{array}$ & 10 \\
\hline Liu et al & 2013 & Lung cancer & $\begin{array}{l}\text { A549 and HI } 975 \\
\text { cell lines }\end{array}$ & $\begin{array}{l}\text { Ursolic acid inhibited lung cancer cell invasion and metastasis } \\
\text { through } M T D H / N F-\kappa B / E M T \text { pathway }\end{array}$ & 12 \\
\hline Li et al & 2011 & Breast cancer & MCF-7, NIH3T3 & $\begin{array}{l}\text { MTDH regulates EMT and drives tumor progression in breast } \\
\text { cancer cells through NF- } \mathrm{KB} \text { pathway }\end{array}$ & 15 \\
\hline $\begin{array}{l}\text { Zheng } \\
\text { et al }\end{array}$ & 2014 & Liver cancer & $\begin{array}{l}\text { Human tissue } \\
\text { samples }\end{array}$ & $\begin{array}{l}\text { MTDH is overexpressed in hepatocellular carcinoma, and MTDH } \\
\text { plays a role in regulating tumor progression through EMT; MTDH is } \\
\text { also a potential target to treat hepatocellular carcinoma }\end{array}$ & 23 \\
\hline He et al & 2015 & Lung cancer & $\begin{array}{l}\text { Human tissue } \\
\text { samples; } \mathrm{NCl}- \\
\mathrm{H} 226, \mathrm{NCl}-\mathrm{H} 460 \text {, } \\
\text { L-78, A549, and } \\
\text { Slu-0I }\end{array}$ & $\begin{array}{l}\text { MTDH promotes EMT and aggressive metastasis of lung cancer by } \\
\text { activating Wnt/B-catenin signaling; MTDH is also a potential tool } \\
\text { to develop prognostic biomarker and therapeutic target for lung } \\
\text { cancer }\end{array}$ & 24 \\
\hline Yu et al & 2014 & $\mathrm{SCCHN}$ & $\begin{array}{l}\text { Human tissue } \\
\text { samples; Tu686 } \\
\text { and } 5-8 \mathrm{~F} \text { cell lines }\end{array}$ & $\begin{array}{l}\text { A negative correlation between MTDH and E-cadherin has been } \\
\text { detected in the carcinoma; MTDH and EMT biomarkers are } \\
\text { prognostic tools in SCCHN; MTDH might induce EMT through } \\
\text { AKT signaling pathway to promote SCCHN metastasis }\end{array}$ & 25 \\
\hline Tang et al & 2014 & Osteosarcoma & $\begin{array}{l}\text { Human tissue } \\
\text { samples; U2OS, } \\
\text { SaOS-2, SoSP-M, } \\
\text { OS-990I, MG-63, } \\
\text { and SoSP-9607 } \\
\text { cell lines }\end{array}$ & $\begin{array}{l}\text { MTDH promotes metastasis by regulating EMT in OS; } \\
\text { overexpressed MTDH in OS can activate NF-KB, AKT, } \\
\text { and ERK pathways in vivo and vitro; MTDH could be a therapeutic } \\
\text { target in OS }\end{array}$ & 26 \\
\hline Zhu et al & 2011 & Liver cancer & $\begin{array}{l}\text { Human tissue } \\
\text { samples; nude } \\
\text { mice; MHCC97-L, } \\
\text { MHCC97-H, } \\
\text { HCCLM3, and } \\
\text { HepG2k cell lines }\end{array}$ & $\begin{array}{l}\text { MTDH may induce EMT and promote HCC metastasis; MTDH may } \\
\text { be a potential biomarker for evaluating prognosis and serve as a } \\
\text { target for therapy }\end{array}$ & 27 \\
\hline Liu et al & 2015 & Lung cancer & $\begin{array}{l}\text { A549 and HEK- } \\
293 T \text { cell lines }\end{array}$ & $\begin{array}{l}\text { miRNA-30a directly acts on MTDH and mesenchymal biomarkers } \\
\text { to regulate cancer cell migration and invasiveness; MTDH } 3^{\prime} \text {-UTR } \\
\text { has been verified as ceRNA that regulates EMT in non-small-cell } \\
\text { lung cancer indirectly }\end{array}$ & 28 \\
\hline $\begin{array}{l}\text { Zhang } \\
\text { et al }\end{array}$ & 2015 & $\begin{array}{l}\text { Cervical } \\
\text { cancer }\end{array}$ & $\begin{array}{l}\text { Human tissue } \\
\text { samples; } \mathrm{SiHa}\end{array}$ & $\begin{array}{l}\text { MTDH mediates CCL20/CCR6-induced EMT through ERKI/2 and } \\
\text { AKT pathway in cervical cancer }\end{array}$ & 29 \\
\hline Song et al & 2015 & $\begin{array}{l}\text { Cervical } \\
\text { cancer }\end{array}$ & $\begin{array}{l}\text { Human tissue } \\
\text { samples; } \mathrm{SiHa}\end{array}$ & $\begin{array}{l}\text { AEG-I regulates EMT through Wnt signaling pathway in cervical } \\
\text { squamous cell carcinoma and is associated with tumor progression }\end{array}$ & 30 \\
\hline Pan et al & 2015 & TSCC & $\begin{array}{l}\text { Human tissue } \\
\text { samples; nude } \\
\text { mice; UMI and } \\
\text { Scc } 25 \text { cell lines }\end{array}$ & $\begin{array}{l}\text { MTDH promotes TSCC invasion through EMT, and MTDH } \\
\text { combined with EMT biomarkers had better performance in } \\
\text { predicting death in TSCC; MTDH-mediated invasion, migration, and } \\
\text { EMT in TSCC was through Wnt/PCP-Rho-JNK pathway }\end{array}$ & 31 \\
\hline
\end{tabular}


Table I (Continued)

\begin{tabular}{|c|c|c|c|c|c|}
\hline $\begin{array}{l}\text { First } \\
\text { author }\end{array}$ & $\begin{array}{l}\text { Publication } \\
\text { year }\end{array}$ & Cancer type & Specimens & Main conclusions & References \\
\hline $\begin{array}{l}\text { Ward } \\
\text { et al }\end{array}$ & 2013 & Breast cancer & $\begin{array}{l}\text { Human tissue } \\
\text { samples; MCF-7, } \\
\text { MDA-MB-23I, } \\
\text { HI703, HI299, } \\
\text { HEK-293FT, and } \\
\text { Ovcar-5 }\end{array}$ & $\begin{array}{l}\text { miRNA-375 targets MTDH to regulate EMT in breast cancer and is } \\
\text { associated with chemotherapy resistance }\end{array}$ & 32 \\
\hline $\begin{array}{l}\text { Srivastava } \\
\text { et al }\end{array}$ & 2015 & Liver cancer & $\begin{array}{l}\text { Mice; primary } \\
\text { mouse } \\
\text { hepatocytes }\end{array}$ & $\begin{array}{l}\text { Liver cancer invasion and metastasis might be explained by } \\
\text { sustained EMT induced by combined expression of AEG-I } \\
\text { and c-Myc }\end{array}$ & 39 \\
\hline $\begin{array}{l}\text { Wang } \\
\text { et al }\end{array}$ & 2015 & $\begin{array}{l}\text { Colorectal } \\
\text { cancer }\end{array}$ & $\begin{array}{l}\text { Human tissue } \\
\text { samples; HT29, } \\
\text { DLD-I, HCT- } \\
\text { I5, CoL0320, } \\
\text { SW480, and } \\
\text { SW620 cell lines }\end{array}$ & $\begin{array}{l}\text { RARRES3 suppresses colorectal cancer metastasis and EMT by } \\
\text { acting on MTDH }\end{array}$ & 40 \\
\hline Li et al & 2015 & Breast cancer & $\begin{array}{l}\text { Human tissue } \\
\text { samples; MCF-7 } \\
\text { and MDA-MB- } \\
\text { 23I }\end{array}$ & $\begin{array}{l}\text { miRNA-I } 53 \text { suppresses breast cancer EMT, migration, and invasion } \\
\text { by targeting MTDH }\end{array}$ & 41 \\
\hline Zhu et al & 2014 & Liver cancer & $\begin{array}{l}\text { Nude mice; } \\
\text { HCCLM3 and } \\
\text { HUVEC cell lines }\end{array}$ & $\begin{array}{l}\text { miRNA-302c inhibited liver cancer cell growth, through targeting } \\
\text { of MTDH } 3^{\prime}-\text { UTR and suppression of mesenchymal transition of } \\
\text { endothelial cells; miR-302c and MTDH are potential treatment } \\
\text { targets in HCC }\end{array}$ & 42 \\
\hline Suh et al & 2014 & Lung cancer & $\begin{array}{l}\text { Human tissue } \\
\text { samples; nude } \\
\text { mice; A549, } \\
\text { H460, and HI299 }\end{array}$ & $\begin{array}{l}\text { Fragile histidine triad (FHIT) upregulates miRNA- } 30 \mathrm{c} \text {, and miRNA- } \\
\text { 30c targets MTDH 3'-UTR to regulate lung cancer metastasis } \\
\text { and EMT }\end{array}$ & 43 \\
\hline $\begin{array}{l}\text { Wang } \\
\text { et al }\end{array}$ & 2013 & Breast cancer & MDA-MB-23I & $\begin{array}{l}\text { SU6668 suppresses breast cancer progression by acting on EMT, } \\
\text { inducing cancer cell DNA polyploidization, and inhibiting expression } \\
\text { of MTDH }\end{array}$ & 48 \\
\hline $\begin{array}{l}\text { Zheng } \\
\text { et al }\end{array}$ & 2014 & Liver cancer & $\mathrm{MHCC} 97-\mathrm{H}$ & $\begin{array}{l}\text { Huaier polysaccharides inhibited hepatocarcinoma cell proliferation, } \\
\text { invasiveness, and metastasis by suppressing expression of MTDH } \\
\text { and reversing EMT }\end{array}$ & 53 \\
\hline
\end{tabular}

Abbreviations: AEG-I, astrocyte elevated gene-I; ceRNA, competitive endogenous RNA; EMT, epithelial-mesenchymal transition; HCC, hepatocellular carcinoma; HUVEC, human umbilical vein endothelial cells; LSCC, laryngeal squamous cell carcinoma; MTDH, metadherin; OS, osteosarcoma; SCCHN, squamous cell carcinoma of the head and neck; TSCC, tongue squamous cell carcinoma; UTR, untranslated region; RARRES3, Retinoic acid receptor responder 3; PCP, planar cell polarity.

MTDH, E-cadherin, and vimentin in these two types of liver tissues was significantly different. Further analysis indicated positive correlation between MTDH and vimentin, as well as negative correlation between MTDH and E-cadherin expression, in liver cancer tissues. ${ }^{23}$ Analysis of the relationship between MTDH and EMT biomarkers shows that they are expressed similarly in lung cancer. ${ }^{24}$ Results from laryngeal squamous cell carcinoma (LSCC) and squamous cell carcinoma of the head and neck (SCCHN) also showed a negative correlation between MTDH and E-cadherin. ${ }^{10,25}$ To further clarify the expressions of these biomarkers in metastatic and nonmetastatic osteosarcoma (OS) tissues, four metastatic cases and four nonmetastatic cases have been studied. ${ }^{26}$ Higher expressions of MTDH and mesenchymal biomarkers (N-cadherin and vimentin), as well as lower expression of E-cadherin, were verified in metastatic tissues, compared to nonmetastatic ones. ${ }^{26}$
In vitro studies ${ }^{25-27}$ also showed overexpression of MTDH and mesenchymal biomarkers and decreased expressions of epithelial biomarkers in liver cancer cells (MHCC97-L, MHCC97-H, HCCLM3, HepG2), SCCHN cells (TU686, 5-8F), and OS cells (U2OS, SOSP-M). In non-small-cell lung cancer, MTDH was upregulated when EMT was induced by transforming growth factor- $\beta$ and tumor necrosis factor- $\alpha$ in A549 cells. ${ }^{28}$ A positive correlation between overexpression of MTDH and mesenchymal biomarkers has been established in this cell model. ${ }^{28}$

\section{Tumor progression and prognosis}

It has been verified that MTDH is overexpressed in some malignancies, and $M T D H$ is considered an important oncogene. ${ }^{6} \mathrm{MTDH}$ overexpression is also associated with carcinoma progression, invasiveness, angiogenesis, and metastasis of carcinomas. ${ }^{1,59}$ EMT has also been proven to be 
an important process in cancer progression and metastasis. ${ }^{14}$ Researchers ${ }^{10,23,25}$ have already shown a correlation between expressions of MTDH and EMT.

In a study by Zheng et al, ${ }^{23}$ MTDH and EMT biomarkers were significantly associated with the tumor-node-metastasis (TNM) stage and Edmonson grade of liver carcinoma, and a potential link between carcinoma progression, MTDH overexpression, and EMT had been established. In SCCHN analysis, a significant correlation had also been established between MTDH overexpression, decreased E-cadherin expression, and clinicopathological parameters, including primary tumor site, T-classification, clinical stage, metastasis, and recurrence. ${ }^{25}$ Similar conclusions were also arrived in LSCC and cervical cancer. ${ }^{10,29,30}$ Through analysis of metastatic and nonmetastatic OS tissues, it was proposed that metastasis may be regulated by MTDH through the EMT process. ${ }^{26}$ Nude mice experiments also demonstrated upregulated MTDH promoting tongue squamous cell carcinoma (TSCC) invasion, along with an upregulation of vimentin and downregulation of E-cadherin. ${ }^{31}$

Results of in vitro cell experiments further confirmed that EMT is regulated by MTDH and demonstrated their significant effects on invasiveness, metastasis, and progression in carcinoma. In liver carcinoma cell lines, inhibition of MTDH by short hairpin RNA (shRNA) decreased expression of N-cadherin and transcription factor Snail, in addition to upregulating E-cadherin. ${ }^{27}$ Knockdown of $M T D H$ in HeLa cells and the TSCC cell line UM1 also yielded similar results as in liver carcinoma. ${ }^{2,31}$ EMT induction by CCL-20 in $\mathrm{SiHa}$ cell lines was also been eliminated by silencing $M T D H$ expression. ${ }^{29}$ On further investigation of effect of MTDH on EMT in carcinoma cell lines, EMT was found to be restored or reversed by upregulating or downregulating $M T D H$, respectively. ${ }^{24,30} \mathrm{MTDH}$ is an important regulator of EMT in carcinoma. Inhibition of MTDH expression decreases migration, invasiveness, and colony formation in liver, cervical cancer, and non-small-cell lung cancer cell lines. , 27,28,30 $^{2}$ Overexpressed MTDH increases migration and invasiveness in breast cancer and cervical cancer cell lines. ${ }^{15,30}$ Orthotopic mouse model also confirmed that MTDH promotes metastasis in lung cancer cells (Slu-01) by means of regulating EMT. ${ }^{24}$ EMT is an important process induced by MTDH, and it regulates biological functions, such as progression, invasiveness, and metastasis, in cancer cells. 2,15,24,27,30

In clinical analysis, MTDH is also an important factor associated with prognosis of carcinomas. In SCCHN and LSCC survival analysis, MTDH overexpression and E-cadherin decreased expression were negatively correlated with overall survival and disease-free survival. ${ }^{10,25}$ Further statistical analysis revealed that $\mathrm{MTDH}$ is an independent prognostic factor in SCCHN and LSCC. ${ }^{10,25}$ However, both Pan et $\mathrm{al}^{31}$ and $\mathrm{He}$ et $\mathrm{al}^{24}$ hold the viewpoint that the combination of MTDH and EMT biomarkers had better performance in predicting death in TSCC and lung cancer. In breast cancer patients treated with tamoxifen, MTDH overexpression is a poor factor associated with relapse-free survival. ${ }^{32}$

In summary, MTDH expression is a potential prognostic factor in cancer, and this could be explained by the biological effects mediated by MTDH through regulation of EMT. Invasiveness, progression, and metastasis are regulated by MTDH through EMT, as already verified in cancer cell lines. ${ }^{2,15,24,27,28,30}$ These biological effects are important factors associated with development of cancer and survival of patients.

\section{Signal pathways}

MTDH exhibits many biological effects on cancers, and these could be mediated by signal pathways, proteins, and factors. Studies $^{27,33}$ have shown that the NF- $\kappa B$, Wnt/ $\beta$-catenin, PI3K/ AKT, and MAPK pathways are activated as part of the MTDHmediated biological effects in cancers. Some proteins or factors, such as Staphylococcal nuclease domain containing protein 1 (SND1) and cytoplasmic polyadenylation element-binding protein 1 (CPEB1), also interact with the $M T D H$ gene to affect MTDH expression and activity. ${ }^{33-36}$ Small noncoding RNAs, termed microRNAs or miRNAs, including miRNA-375, miRNA-137, miRNA-30a, and so on, also have been confirmed to regulate MTDH in cancer cell lines; MTDH has also been verified as a target of these miRNAs in carcinoma. ${ }^{11,37,38}$

Similar to MTDH, EMT could also be regulated by many pathways and factors. NF- $\kappa \mathrm{B}, \mathrm{Wnt} / \beta$-catenin, PI3K/AKT, and miRNAs have also been confirmed in mediating EMT in carcinomas. ${ }^{14}$ Recent studies have shown some signal pathways regulating EMT through MTDH in cancers. ${ }^{2,15,25,30}$

In SCCHN, PI3K/AKT pathways are activated during the processes of EMT and metastasis, and they are regulated by MTDH. ${ }^{25}$ It has been identified that NF- $\kappa \mathrm{B}$ is involved in EMT induced by MTDH in breast and cervical cancer cell lines. ${ }^{2,15}$ Song et $\mathrm{al}^{30}$ investigated the pathways through which MTDH exerts its effects on both EMT and the biological behavior of cervical squamous cell carcinoma (CSCC) cells; they propose that the $\mathrm{Wnt} / \beta$-catenin pathway, apart from $\mathrm{PI} 3 \mathrm{~K} / \mathrm{AKT}$ or NF- $\kappa \mathrm{B}$, regulates EMT in CSCC. He et $\mathrm{al}^{24}$ also found that the $\mathrm{Wnt} / \beta$-catenin pathways had been activated in the cascade of EMT regulated by MTDH, and in this process, GSK-3 $\beta$ and CKI $\delta$ are involved. However, MTDH-mediated invasion, migration, and EMT were studied in TSCC, and Pan et $\mathrm{al}^{31}$ consider that this process is regulated by the Wnt/PCPRho-JNK pathway. In OS cell lines, EMT has been found to 


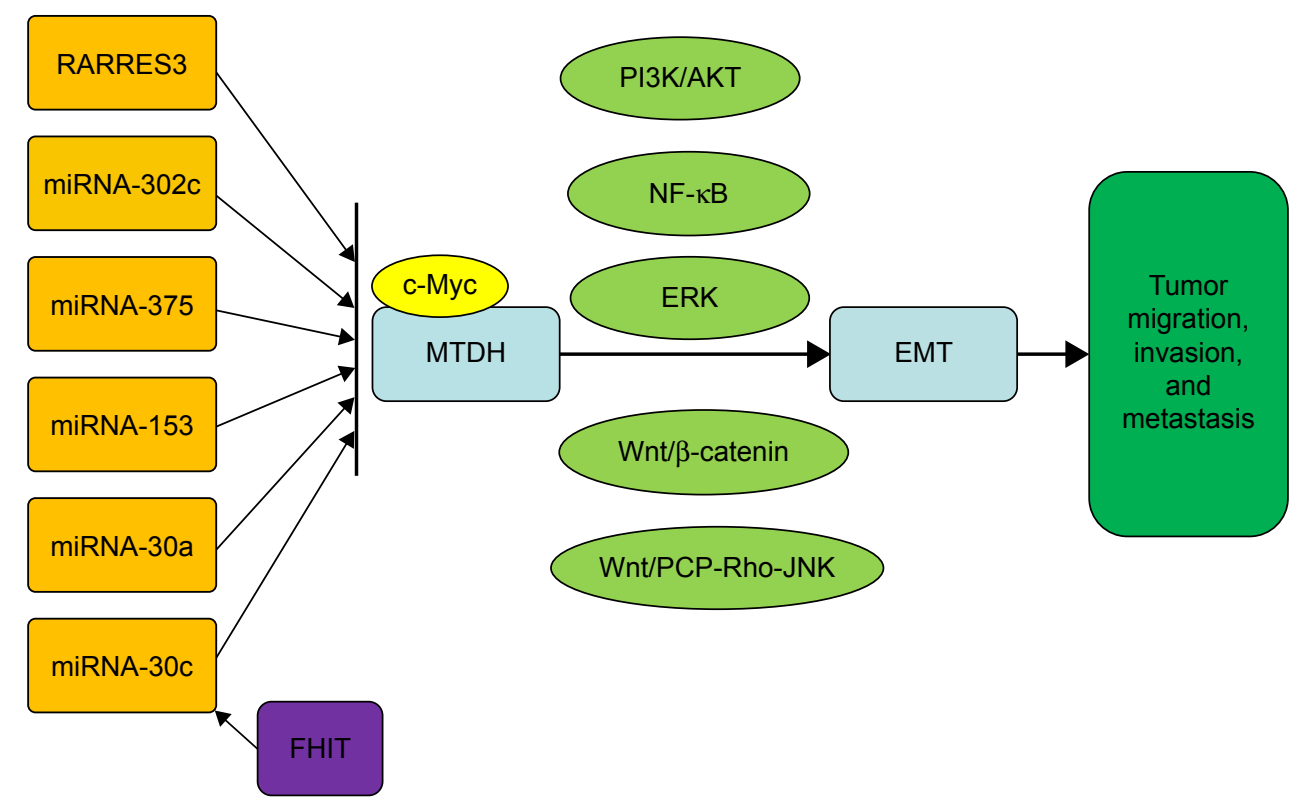

Figure I A summary of the complex signal pathway network involved in EMT regulation by MTDH in carcinoma.

Abbreviations: EMT, epithelial-mesenchymal transition; FHIT, fragile histidine triad; miRNA, microRNA; MTDH, metadherin; RARRES3, Retinoic acid receptor responder 3; PCP, planar cell polarity.

be reversed by inhibition of MTDH through upregulation of Elf-5. ${ }^{26}$ Overexpressed MTDH has also been confirmed to activate NF- $\kappa \mathrm{B}, \mathrm{AKT}$, and ERK pathways in OS both in vivo and in vitro. ${ }^{26}$ ERK $1 / 2$ and AKT pathways were involved in MTDH mediation of EMT, which was induced by CCL20/ CCR6. ${ }^{29}$ In a cooperation of overexpression AEG-1 and c-Myc mice model (Alb/AEG-1/c-Myc), Srivastava et al ${ }^{39}$ found that invasion and metastasis in liver cancer might be explained by the sustained EMT induced by the combined expression of $A E G-1$ and $c-M y c$. MTDH also has been detected to be an important mediator in signal transduction of carcinoma suppressors, eg, RARRES3 suppresses colorectal cancer metastasis and EMT by acting on MTDH. ${ }^{40}$

Recent studies reveal that miRNAs constitute a class of vital regulators of MTDH and EMT, and some of them are targeting MTDH to regulate EMT in cancers. ${ }^{32,40}$ Ward et $\mathrm{al}^{32}$ suggested that miRNA-375 targets MTDH to regulate EMT in breast cancer, and this process is associated with chemotherapy resistance. Li et $\mathrm{al}^{41}$ indicated that miRNA-153 suppresses EMT, migration, and invasion by targeting MTDH. miRNA-302c inhibits growth of liver cancer cells, through targeting of the $3^{\prime}$-untranslated region (UTR) of MTDH and suppressing the EMT of endothelial cells. ${ }^{42}$ Fragile histidine triad (FHIT) upregulates miRNA-30c, and then miRNA-30c targets the $M T D H 3^{\prime}$-UTR to regulate lung cancer metastasis and EMT. ${ }^{43}$ miRNA-30a is a suppressing regulator of nonsmall-cell lung cancer, and it can directly act on MTDH and mesenchymal biomarkers to regulate cancer cell migration and invasiveness. ${ }^{28}$ MTDH 3 '-UTR has also been verified as a ceRNA (competitive endogenous RNA) that regulates EMT in non-small-cell lung cancer indirectly. ${ }^{28}$

A complex network of signaling pathways for EMT regulation by MTDH has been established (Figure 1), and their relationships and targets are under further study.

\section{Therapeutic targets}

MTDH has been demonstrated to regulate EMT in cancers, and it has been considered to be a potential therapeutic target. In breast and cervical cancer cells, knockdown of $M T D H$ enhances the sensitivity to chemotherapy and reverses EMT.,32 Recent studies highlight MTDH as an important target in the treatment of breast, cervical, and non-small-cell lung cancer, as well as for OS. ${ }^{2,15,24,26}$

SU6668 is an angiogenesis inhibitor targeting multiple tyrosine kinase receptors. ${ }^{44}$ SU6668 has been reported to be an important anticancer agent in colorectal cancer, endometrial cancer, and mesothelioma. ${ }^{45-47}$ A recent study ${ }^{48}$ has revealed that MTDH and EMT are regulated by SU6668. In breast cancer cells, SU6668 suppressed proliferation and metastasis by reversing EMT, inducing cancer cell DNA polyploidization, and inhibiting expression of $\mathrm{MTDH}{ }^{48}$

Natural source drugs, which are derived or extracted from plants, microbes, and marine organisms, show biological activity and anticancer effects, and they account for $>60 \%$ of anticancer drugs currently. ${ }^{49}$ Chemoprevention refers to administration of nontoxic substances to disturb carcinogenesis and invasiveness; natural products are an important part of chemoprevention. ${ }^{50}$ 
Ursolic acid (UA) is a pentacyclic triterpene acid extracted from many plants. ${ }^{51}$ Recent studies reveal that UA exhibits anticancer activity against various cancers by inducing apoptosis, by inhibiting proliferation, invasiveness, and metastasis, as well as by antiangiogenesis. ${ }^{12,51}$ UA decreases MTDH expression to inhibit EMT in lung cancer cells; furthermore, a study ${ }^{12}$ has shown that the NF-KB pathway is involved in this process. In this cited study, Liu et $\mathrm{al}^{12}$ provide a new strategy for both anticancer approach and chemoprevention by targeting MTDH through application of natural products.

Polysaccharides extracted from Huaier showed anticancer effects and immunomodulation. ${ }^{52}$ Zheng et al ${ }^{53}$ proved that Huaier polysaccharides exhibited inhibition of hepatocarcinoma cell proliferation, invasiveness, and metastasis by suppressing expression of MTDH and reversing EMT. Another experiment performed by Zheng et $\mathrm{al}^{54}$ again showed that $M T D H$ downregulation enhanced the suppression effects of the Huaier polysaccharides on hepatocarcinoma cells. Further investigation revealed that the PI3K/AKT pathway was inhibited and the natural killer cell-mediated immune response was enhanced in the process of inhibition of hepatocarcinoma cells by Huaier polysaccharides induced by MTDH shRNA. ${ }^{54}$

\section{Perspectives}

MTDH plays a vital role in cancer progression, invasiveness, and metastasis, and EMT is induced in the process. MTDH and EMT are associated with chemotherapy resistance and prognosis. Complex signal pathways are also involved in the regulation of EMT by MTDH. Some drugs target MTDH to regulate cancer progression and metastasis induced by EMT. Some perspectives on regulation of EMT by MTDH are listed as follows.

First, many more tissue specimens and more follow-up data should be included in future studies. This increase in the sample size could reduce the errors or bias that may have crept into this study. Multicenter studies are an ideal way to arrive at more accurate conclusions. MTDH and EMT may serve as biomarkers useful to evaluate cancer progression, predict prognosis, and guide therapy.

Second, cancer types studied may also be increased. Currently, studies are limited to EMT regulation by MTDH in liver cancer, breast cancer, SCCHN, non-small-cell lung cancer, cervical cancer, colorectal cancer, TSCC, and OS. Other cancers, such as meningioma, as well as hematologic and digestive malignancies, could also be studied to investigate EMT induction by MTDH. This is a good method to broaden the application of MTDH and EMT biomarkers in cancers.
Third, signal pathways should be explored further. Currently, the PI3K/AKT, NF- $\mathrm{KB}$, and ERK pathways, as well as miRNAs, are known to be involved in EMT mediated by MTDH. Detailed pathway networks could be studied further, and targeted therapy may be explored based on these studies.

Finally, chemoprevention using drugs developed from natural products is a therapeutic direction based on the regulation of MTDH and EMT. Further research on molecular mechanisms and biochemistry should be conducted. Chemotherapeutic side effects may be reduced through this therapeutic regimen.

\section{Acknowledgments}

This work was supported by the Free Exploration Project for Undergraduates in Central South University (number 2282014bks198).

\section{Disclosure}

The authors report no conflicts of interest in this work.

\section{References}

1. Wang Z, Wei YB, Gao YL, Yan B, Yang JR, Guo Q. Metadherin in prostate, bladder, and kidney cancer: a systematic review. Mol Clin Oncol. 2014; 2(6):1139-1144.

2. Liu X, Wang D, Liu H, et al. Knockdown of astrocyte elevated gene-1 (AEG-1) in cervical cancer cells decreases their invasiveness, epithelial to mesenchymal transition, and chemoresistance. Cell Cycle. 2014;13(11): 1702-1707.

3. Su ZZ, Kang DC, Chen Y, et al. Identification and cloning of human astrocyte genes displaying elevated expression after infection with HIV-1 or exposure to HIV-1 envelope glycoprotein by rapid subtraction hybridization, RaSH. Oncogene. 2002;21(22):3592-3602.

4. Dong L, Qin S, Li Y, et al. High expression of astrocyte elevated gene-1 is associated with clinical staging, metastasis, and unfavorable prognosis in gastric carcinoma. Tumour Biol. 2014;36(3):2169-2178.

5. Hu G, Wei Y, Kang Y. The multifaceted role of MTDH/AEG-1 in cancer progression. Clin Cancer Res. 2009;15(18):5615-5620.

6. Emdad L, Lee SG, Su ZZ, et al. Astrocyte elevated gene-1 (AEG-1) functions as an oncogene and regulates angiogenesis. Proc Natl Acad Sci U S A. 2009;106(50):21300-21305.

7. Hu G, Chong RA, Yang Q, et al. MTDH activation by $8 \mathrm{q} 22$ genomic gain promotes chemoresistance and metastasis of poor-prognosis breast cancer. Cancer Cell. 2009;15(1):9-20.

8. Tokunaga E, Nakashima Y, Yamashita N, et al. Overexpression of metadherin/MTDH is associated with an aggressive phenotype and a poor prognosis in invasive breast cancer. Breast Cancer. 2014;21(3):341-349.

9. Emdad L, Sarkar D, Su ZZ, et al. Astrocyte elevated gene-1: recent insights into a novel gene involved in tumor progression, metastasis and neurodegeneration. Pharmacol Ther. 2007;114(2):155-170.

10. Liu Y, Su Z, Li G, et al. Increased expression of metadherin protein predicts worse disease-free and overall survival in laryngeal squamous cell carcinoma. Int J Cancer. 2013;133(3):671-679.

11. Zhang N, Wang X, Huo Q, et al. MicroRNA-30a suppresses breast tumor growth and metastasis by targeting metadherin. Oncogene. 2014;33(24): 3119-3128.

12. Liu K, Guo L, Miao L, et al. Ursolic acid inhibits epithelial-mesenchymal transition by suppressing the expression of astrocyte-elevated gene-1 in human nonsmall cell lung cancer A549 cells. Anticancer Drugs. 2013; 24(5):494-503. 
13. Thiery JP, Acloque H, Huang RY, Nieto MA. Epithelial-mesenchymal transitions in development and disease. Cell. 2009;139(5):871-890.

14. Iwatsuki M, Mimori K, Yokobori T, et al. Epithelial-mesenchymal transition in cancer development and its clinical significance. Cancer Sci. 2010;101(2):293-299.

15. Li X, Kong X, Huo Q, et al. Metadherin enhances the invasiveness of breast cancer cells by inducing epithelial to mesenchymal transition. Cancer Sci. 2011;102(6):1151-1157.

16. Gong Z, Liu W, You N, et al. Prognostic significance of metadherin overexpression in hepatitis B virus-related hepatocellular carcinoma. Oncol Rep. 2012;27(6):2073-2079.

17. Song H, LiC, LiR, Geng J. Prognostic significance of AEG-1 expression in colorectal carcinoma. Int J Colorectal Dis. 2010;25(10):1201-1209.

18. Ke ZF, Mao X, Zeng C, He S, Li S, Wang LT. AEG-1 expression characteristics in human non-small cell lung cancer and its relationship with apoptosis. Med Oncol. 2013;30(1):383.

19. Thirkettle HJ, Girling J, Warren AY, et al. LYRIC/AEG-1 is targeted to different subcellular compartments by ubiquitinylation and intrinsic nuclear localization signals. Clin Cancer Res. 2009;15(9): 3003-3013.

20. Wan L, Hu G, Wei Y, et al. Genetic ablation of metadherin inhibits autochthonous prostate cancer progression and metastasis. Cancer Res. 2014;74(18):5336-5347.

21. Gwak JM, Kim HJ, Kim EJ, et al. MicroRNA-9 is associated with epithelial-mesenchymal transition, breast cancer stem cell phenotype, and tumor progression in breast cancer. Breast Cancer Res Treat. 2014;147(1): $39-49$.

22. Murali AK, Norris JS. Differential expression of epithelial and mesenchymal proteins in a panel of prostate cancer cell lines. J Urol. 2012 188(2):632-638.

23. Zheng J, Li C, Wu X, et al. Astrocyte elevated gene- 1 is a novel biomarker of epithelial-mesenchymal transition and progression of hepatocellular carcinoma in two China regions. Tumour Biol. 2014;35(3): 2265-2269.

24. He W, He S, Wang Z, et al. Astrocyte elevated gene-1(AEG-1) induces epithelial-mesenchymal transition in lung cancer through activating Wnt/beta-catenin signaling. BMC Cancer. 2015;15:107.

25. Yu C, Liu Y, Tan $\mathrm{H}$, et al. Metadherin regulates metastasis of squamous cell carcinoma of the head and neck via AKT signalling pathwaymediated epithelial-mesenchymal transition. Cancer Lett. 2014; 343(2):258-267.

26. Tang J, Shen L, Yang Q, Zhang C. Overexpression of metadherin mediates metastasis of osteosarcoma by regulating epithelial-mesenchymal transition. Cell Prolif. 2014;47(5):427-434.

27. Zhu K, Dai Z, Pan Q, et al. Metadherin promotes hepatocellular carcinoma metastasis through induction of epithelial-mesenchymal transition. Clin Cancer Res. 2011;17(23):7294-7302.

28. Liu K, Guo L, Guo Y, et al. AEG-1 3'-untranslated region functions as a ceRNA in inducing epithelial-mesenchymal transition of human nonsmall cell lung cancer by regulating miR-30a activity. Eur J Cell Biol. 2015;94(1):22-31.

29. Zhang J, Zhu D, Lv Q, Yi Y, Li F, Zhang W. The key role of astrocyte elevated gene-1 in CCR6-induced EMT in cervical cancer. Tumour Biol. 2015;36(12):9763-9767.

30. Song E, Yu W, Xiong X, Kuang X, Ai Y, Xiong X. Astrocyte elevated gene-1 promotes progression of cervical squamous cell carcinoma by inducing epithelial-mesenchymal transition via Wnt signaling. Int J Gynecol Cancer. 2015;25(3):345-355.

31. Pan Y, Guo X, Yang Z, et al. AEG-1 activates Wnt/PCP signaling to promote metastasis in tongue squamous cell carcinoma. Oncotarget. 2015; $7(2): 2093-2104$

32. Ward A, Balwierz A, Zhang JD, et al. Re-expression of microRNA375 reverses both tamoxifen resistance and accompanying EMT-like properties in breast cancer. Oncogene. 2013;32(9):1173-1182.

33. Yoo BK, Emdad L, Lee SG, et al. Astrocyte elevated gene-1 (AEG-1): a multifunctional regulator of normal and abnormal physiology. Pharmacol Ther. 2011;130(1):1-8.
34. Blanco MA, Aleckovic M, Hua Y, et al. Identification of staphylococcal nuclease domain-containing 1 (SND1) as a Metadherin-interacting protein with metastasis-promoting functions. J Biol Chem. 2011;286(22): 19982-19992.

35. Kochanek DM, Wells DG. CPEB1 regulates the expression of MTDH/ AEG-1 and glioblastoma cell migration. Mol Cancer Res. 2013; 11:149-160.

36. Wan L, Lu X, Yuan S, et al. MTDH-SND1 interaction is crucial for expansion and activity of tumor-initiating cells in diverse oncogeneand carcinogen-induced mammary tumors. Cancer Cell. 2014;26(1): 92-105.

37. Isozaki Y, Hoshino I, Nohata N, et al. Identification of novel molecular targets regulated by tumor suppressive miR-375 induced by histone acetylation in esophageal squamous cell carcinoma. Int J Oncol. 2012; 41(3):985-994.

38. Guo J, Xia B, Meng F, Lou G. miR-137 suppresses cell growth in ovarian cancer by targeting AEG-1. Biochem Biophys Res Commun. 2013; 441(2):357-363.

39. Srivastava J, Siddiq A, Gredler R, et al. Astrocyte elevated gene-1 (AEG-1) and c-Myc cooperate to promote hepatocarcinogenesis Hepatology. 2015;61(3):915-929.

40. Wang Z, Wang L, Hu J, et al. RARRES3 suppressed metastasis through suppression of MTDH to regulate epithelial-mesenchymal transition in colorectal cancer. Am J Cancer Res. 2015;5(6):1988-1999.

41. Li W, Zhai L, Zhao C, Lv S. MiR-153 inhibits epithelial-mesenchymal transition by targeting metadherin in human breast cancer. Breast Cancer Res Treat. 2015;150(3):501-509.

42. Zhu K, Pan Q, Jia LQ, et al. MiR-302c inhibits tumor growth of hepatocellular carcinoma by suppressing the endothelial-mesenchymal transition of endothelial cells. Sci Rep. 2014;4:5524.

43. Suh SS, Yoo JY, Cui R, et al. FHIT suppresses epithelial-mesenchymal transition (EMT) and metastasis in lung cancer through modulation of microRNAs. PLoS Genet. 2014;10(10):e1004652.

44. Hoekman K. SU6668, a multitargeted angiogenesis inhibitor. Cancer J. 2001;7(suppl 3):S134-S138.

45. Ge Y, Ding Y, Zhang J, Li Z, Li Z. Effect of angiogenesis inhibitor SU6668 in combination with 5-Fu on liver metastasis from transplantation tumors of human colorectal cancer in nude mice. Int J Clin Exp Med. 2014;7(10):3578-3582.

46. Machida S, Saga Y, Takei Y, et al. Combination therapy of tyrosine kinase receptor inhibitor TSU-68 (SU6668) and paclitaxel inhibits subcutaneous xenografts of endometrial cancer. Mol Med Rep. 2008;1(6): 843-846.

47. Van TT, Hanibuchi M, Goto H, et al. SU6668, a multiple tyrosine kinase inhibitor, inhibits progression of human malignant pleural mesothelioma in an orthotopic model. Respirology. 2012;17(6):984-990.

48. Wang L, Liu Z, Ma D, et al. SU6668 suppresses proliferation of triple negative breast cancer cells through down-regulating MTDH expression. Cancer Cell Int. 2013;13(1):88.

49. Dall'Acqua S. Natural products as antimitotic agents. Curr Top Med Chem. 2014;14(20):2272-2285.

50. Kundu JK, Chun KS. The promise of dried fruits in cancer chemoprevention. Asian Pac J Cancer Prev. 2014;15(8):3343-3352.

51. Zang LL, Wu BN, Lin Y, Wang J, Fu L, Tang ZY. Research progress of ursolic acid's anti-tumor actions. Chin J Integr Med. 2014;20(1): 72-79.

52. Sun Y, Sun T, Wang F, et al. A polysaccharide from the fungi of Huaier exhibits anti-tumor potential and immunomodulatory effects. Carbohydr Polym. 2013;92(1):577-582.

53. Zheng J, Li C, Wu X, et al. Huaier polysaccharides suppresses hepatocarcinoma MHCC97-H cell metastasis via inactivation of EMT and AEG-1 pathway. Int J Biol Macromol. 2014;64:106-110.

54. Zheng J, Li C, Wu X, et al. Astrocyte elevated gene-1 (AEG-1) shRNA sensitizes Huaier polysaccharide (HP)-induced anti-metastatic potency via inactivating downstream P13K/Akt pathway as well as augmenting cell-mediated immune response. Tumour Biol. 2014;35(5): $4219-4224$. 


\section{Publish your work in this journal}

OncoTargets and Therapy is an international, peer-reviewed, open access journal focusing on the pathological basis of all cancers, potential targets for therapy and treatment protocols employed to improve the management of cancer patients. The journal also focuses on the impact of management programs and new therapeutic agents and protocols on

patient perspectives such as quality of life, adherence and satisfaction. The manuscript management system is completely online and includes a very quick and fair peer-review system, which is all easy to use. Visit http://www.dovepress.com/testimonials.php to read real quotes from published authors.

Submit your manuscript here: http://www.dovepress.com/oncotargets-and-therapy-journal 